\title{
A case report on placental chorioangioma
}

\author{
Kalyani P. Barde*, Gautam S. Aher, Urmila G. Gavali
}

Department of Obstetrics and Gynecology, DVVPF's Medical College and Hospital, Ahmednagar, Maharashtra, India

Received: 04 August 2021

Accepted: 02 September 2021

\author{
*Correspondence: \\ Dr. Kalyani P. Barde, \\ E-mail: klbarde3@gmail.com
}

Copyright: (c) the author(s), publisher and licensee Medip Academy. This is an open-access article distributed under the terms of the Creative Commons Attribution Non-Commercial License, which permits unrestricted non-commercial use, distribution, and reproduction in any medium, provided the original work is properly cited.

\begin{abstract}
Chorioangioma is the term used to describe an abnormal proliferation of vessels arising from chorionic tissue, which is most commonly observed in the third, and less frequently in the second trimester of pregnancy as a solitary nodule or, less commonly, as multiple nodules. We here report a case of placental chorioangioma which presented as a case of preterm labour. 21 year old primigravida presented to us at 26 weeks of gestation with history of PV leak and pain in abdomen. Ultrasound showed a single live foetus corresponding to 24-26 weeks of gestation with amniotic fluid index (AFI): $5 \mathrm{~cm}$ (oligohydramnios) there was evidence of $58 \times 42 \mathrm{~mm}$ heterogeneously hypoechoic lesion noted over placenta likely s/o chorioangioma. Patient went into spontaneous preterm labour on day 5 and delivered vaginally. Placenta weighted $700 \mathrm{gm}$. A globular mass of size $6 \times 7 \mathrm{~cm}$ was attached to foetal surface of placenta with a pedicle with confirmed the finding of ultrasonography. Placental chorioangioma is associated with high rates of perinatal complications. Most complications may appear early and delivery is problematic due to prematurity. Thus better prenatal investigations and regular follow up is required for early diagnosis and treatment.
\end{abstract}

Keywords: Placental tumour, Colour Doppler, Polyhydramnios, Preterm labour

\section{INTRODUCTION}

Chorioangioma is the term used to describe an abnormal proliferation of vessels arising from chorionic tissue, which is most commonly observed in the third, and less frequently in the second trimester of pregnancy as a solitary nodule or, less commonly, as multiple nodules. With a reported incidence of $1 \%$, it represents the most common tumour of the placenta present over the fatal surface of placenta. ${ }^{1,11}$ The clinical significance of placental chorioangiomas is related to the size of the tumour. Small chorioangiomas, which represent the majority of cases, are of no clinical importance. Those larger than $5 \mathrm{~cm}$ or multiple are usually accompanied by a variety of complications affecting the mother, the developing foetus or the neonate. ${ }^{2}$.

\section{CASE REPORT}

21 year old primigravida married since 8 months presented to us at 26 weeks of gestation with history of PV leak since
2 days and pain in abdomen. On examination, pallor was present over lower palpebral conjunctiva, blood pressure (BP) was $120 / 80 \mathrm{mmHg}$, uterus was 24 week size, changing lie and foetal heart sounds were heard over left spinoumbilical line and the abdomen was relaxed but on per speculum examination there was no leak demonstrable.

Ultrasound showed a single live foetus corresponding to 24-26 weeks of gestation with amniotic fluid index (AFI): $5 \mathrm{~cm}$ (oligohydramnios) with placenta being posterior, with 2 vessel umbilical cord and evidence of $58 \times 42 \mathrm{~mm}$ heterogeneously hypoechoic lesion noted over placenta which showed vascularity on colour Doppler likely s/o chorioangioma. Patient was started on capsule alamine, arginine therapy for borderline oligohydramnios. Two doses of injection betamethasone were given 24 hours apart. However, the patient went into spontaneous preterm labour on day 5. Patient had a vaginal septum which needed to be divided before delivery with local anaesthesia. A female baby was delivered weighing 749 
gm with Apgar of 6, 7, and 8 at 1, 5 and $10 \mathrm{~min}$ respectively.

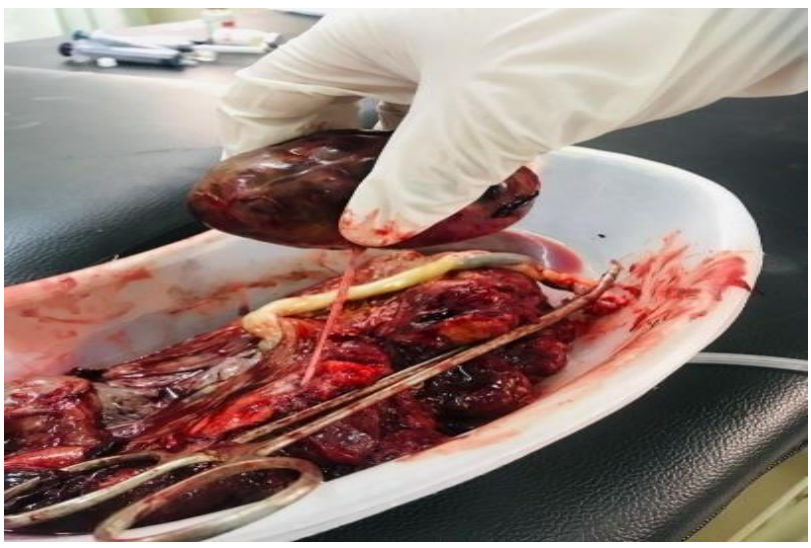

Figure 1: Chorioangioma with stalk connecting to placenta.

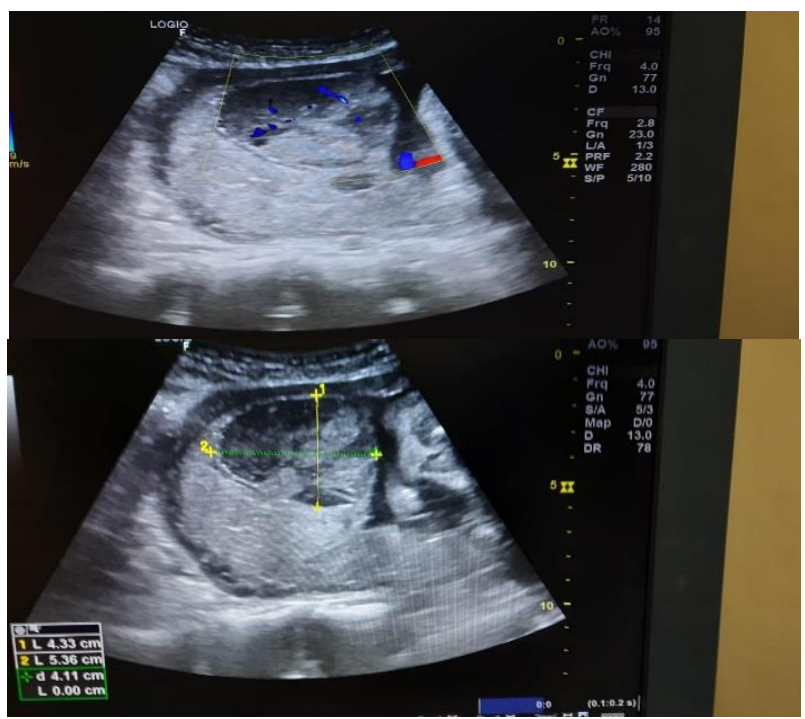

Figure 2: Choriangioma taking vascularity on colour Doppler.

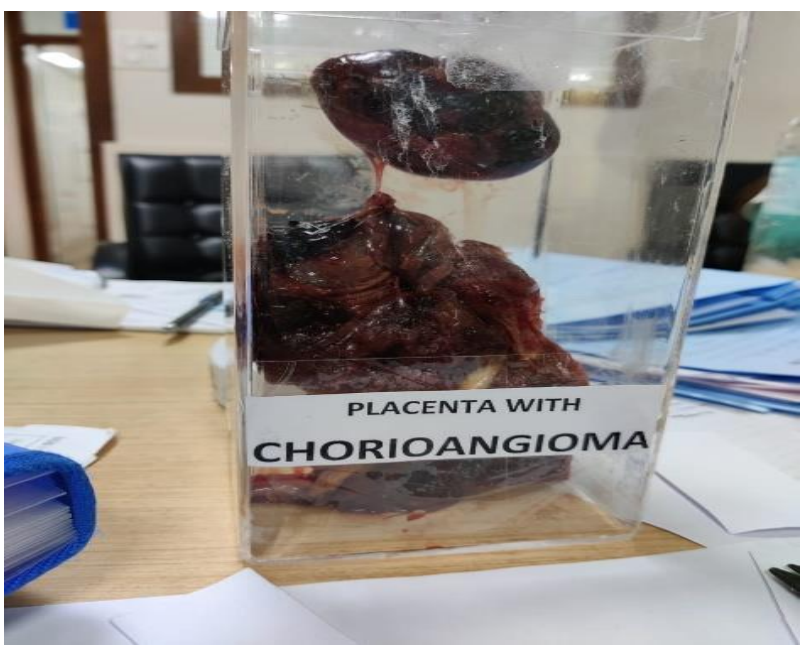

Figure 3: Mounted specimen of chorioangioma.
Placenta weighted 700 gm. A globular mass of size $6 \times 7$ $\mathrm{cm}$ was attached to foetal surface of placenta with a pedicle with confirmed the finding of ultrasonography. Baby expired on $1^{\text {st }}$ postnatal day due to severe hyaline membrane disease.

\section{DISCUSSION}

Chorioangioma placentae was considered as a rare tumour of placenta, but in the recent literature its frequency is about 1\%. ${ }^{1}$ Immunohisto-chemically, the tumour cells show focal staining for cytokeratin 18 , a finding that suggests origin from blood vessels of the chorionic plate and anchoring villi. ${ }^{4}$ Chorangiomata probably arise as malformations of the primitive angioblastic tissue of the early placenta. ${ }^{5}$ Giant chorioangiomas are rare placental tumours, associated with a high prevalence of pregnancy complications and a poor perinatal outcome.The rate of their occurrence rises almost linearly with maternal age: chorangiomas are found most often in women who are over 30 years old. They are often found in primipara and twin pregnancies. 6,12

Prenatal diagnosis of chorioangioma is achieved by ultrasonography with colour Doppler. ${ }^{7}$ The typical appearance is of a vascularised tumour, differentiated from placental haematoma by pulsed Doppler and colour flow mapping. ${ }^{7,8}$ The approach and treatment in case of prenatal diagnosis is dictated by foetal maturation and complications detected in the mother and foetus. These tumours act as large arteriovenous shunts within the placenta, diverting blood away from the foetus. ${ }^{9}$ Growth restriction is due to utero-placental insufficiency from increased functional dead space by the presence of the tumour. $^{6}$

Tumours measuring less than $5 \mathrm{~cm}$ rarely are symptomatic, unlike larger tumours which being highly vascular act as AV shunts causing feral congestive cardiac failure. Mothers present with complications such as preeclampsia, postpartum haemorrhage, preterm labour, placental abruption and polyhydramnios. Polyhydramnios and preterm labour being the most common ones. Other associated complications are hydrops, haemolytic anaemia, congenital anomalies, fatal thrombocytopenia and cardiomegaly. ${ }^{10}$

\section{CONCLUSION}

High rate of perinatal complications are associated with placental chorioangioma. With severe complications, the prognosis is dismal. Most complications may appear early and delivery is problematic due to prematurity. This warrants a need for better prenatal investigations and interventions such as ultrasound and colour Doppler. Regular follow up helps in timely diagnosis and treatment.

Funding: No funding sources

Conflict of interest: None declared

Ethical approval: Not required 


\section{REFERENCES}

1. Wallenburg HCS. Chorangioma of the placenta:thirteen new cases and a review of the literatue from 1939 to 1970 with specialreference to clinical complications. Obstet and Gynecol Survey. 1971;26:411-25.

2. Asadourian LA, Taylor HB. Clinical significance of placental hemangiomas. Obstet Gynecol. 1968;31:551-5.

3. Leonidas JC, Beaty EC, Hall RT. Chorangioma of the placenta: a cause of cardiomegaly and heart failure in the newborn. Am J Roent Rad Ther and Nuc Med. 1975;23:703-7.

4. Lifschitz-Mercer B, Fogel M, Kushnir I, Czernobilsky B. Chorangioma. A cytoskeletal profile. Int J Gynecol Pathol. 1989;8(4):349-56.

5. Lež C, Fures R, Hrgovic Z, Belina S, Fajdic J, Münstedt K. Chorangioma placentae. Rare tumors. 2010;2(4).

6. Zanardini $\mathrm{C}, \mathrm{P}$ apageorghiou $\mathrm{A}$, Bhide A, Thilaganathan B. Giant placental chorioangioma: natural history and pregnancy outcome. Ultrasound Obstet Gynecol. 2010;35:332-6.

7. Prapas N, Liang RI, Hunter D, Copel JA, Lu LC, Pazkash V, Mari G. Color Doppler imaging of placental masses: differential diagnosis and fetal outcome. Ultrasound Obstet Gynecol. 2000;16(6):559-63.

8. Chou MM, Ho ES, Hwang SF, Lee YH, Chan LP, Wen MC. Prenatal diagnosis of placental chorioangioma: contribution of color Doppler ultrasound. Ultrasound Obstet Gynecol. 1994;4(4):332-4.

9. Isaacs H. Fetal hydrops associated with tumors. Am J Perinatol. 2008;25:43-68.

10. Kodandapani S, Shreshta A, Ramkumar V, Rao L. Chorioangioma of placenta: a rare placental cause for adverse fetal outcome. Case Rep Obstet Gynecol. 2012.

11. Lež C, Fures R, Hrgovic Z, Belina S, Fajdic J, Münstedt K. Chorangioma placentae. Rare Tumors. 2010;2(4).

12. Guschmann M, Henrich W, Entezami M, Dudenhausen JW. Chorangioma - new insights into a well-known problem I. Results of a clinical and morphological study of 136 cases. J Perinat Med. 2003;31:163-9.

Cite this article as: Barde KP, Aher GS, Gavali UG. A case report on placental chorioangioma. Int J Reprod Contracept Obstet Gynecol 2021;10:4555-7. 